\title{
Fascioliasis in cattle slaughtered at Gombe abattoir, Nigeria
}

\author{
Lucas Kombe ADANG ${ }^{1}$, Santaya Larit KELA ${ }^{2}$ and Mohammed Bello KASHERE ${ }^{3}$ \\ ${ }^{I}$ Department of Biological Sciences, Federal University Lokoja, PMB 1154 Lokoja, Kogi State, Nigeria. \\ ${ }^{2}$ Department of Biological Sciences, Federal University Kashere, PMB 0182 Gombe, Gombe State, Nigeria. \\ ${ }^{3}$ Department of Biological Sciences, Gombe State University, PMB 127 Gombe, Gombe State, Nigeria. \\ ${ }^{*}$ Corresponding author; E-mail: ladang20@yahoo.com,Tel: +234(0)8033686583.
}

\begin{abstract}
A study to determine the prevalence of fascioliasis in cattle slaughtered at the Gombe township abattoir was carried out from April - June 2009. Three hundred and twenty livers and bile ducts of four breeds of cattle slaughtered at the abattoir were examined for fascioliasis at postmortem. The four breeds of cattle were White Fulani (155), Red Bororo (92), Sokoto Gudali (53) and Muturu (20). An overall prevalence of 83 (25.9\%) was recorded. The white Fulani breed was the most infected, with a prevalence of 56 (36.1\%), Red Bororo 20 (21.7\%), Sokoto Gudali 7 (13.2) and Muturu $0(0.0 \%)$. Inspection by age and sex revealed that adults had a prevalence of $52(37.4 \%)$, young adults $27(20.1)$, and calves $4(8.5 \%)$, while males had a prevalence of 66 $(29.1 \%)$ and females $17(18.3 \%)$. These differences were statistically significant. The study concludes that fascioliasis is prevalent in cattle in Gombe and could be of economic and public health significance.
\end{abstract}

(C) 2015 International Formulae Group. All rights reserved.

Keywords: Prevalence, Fascioliasis, Breed, Cattle, Gombe, Nigeria.

\section{INTRODUCTION}

Cattle suffer from a number of parasitic diseases among which are helminths that lead to morbidity and mortality in the animals. The diseases may also impair development and affect productivity in the animals, such as reduction in milk and meat production, which may apparently affect human nutrition and health (Walha and Banke, 2004). According to Kaplan (2010), liver flukes such as Fasciola sp. may cause a decrease in host fertility by altering normal metabolism and /or balance of sex hormones. Although fluke infected cattle rarely demonstrate clinical disease, subclinical impairment of feed efficiency, growth and fertility can have an important impact on productivity.

Fasciola are parasitic helminths, commonly known as liver flukes. They inhabit the liver and bile ducts of cattle, causing the disease known as fascioliasis which of high veterinary impact but among the most neglected diseases (Young et al., 2010). Henderson (1979) reported the death of 2,000 cattle as a result of liver flukes. Outbreaks of fascioliasis in cattle have been attributed to over-crowding on limited pasture and the presence of snails which are intermediate hosts, which favour heavy build up of parasites and contamination of pasture (Urquhart et al., 1996). Such outbreaks may 
result in heavy mortality of animals, thus making fascioliasis a disease of economic importance. It is also a disease of public health importance, by being a potential zoonosis to humans who consume infected livers. Fasciola hepatica is of global distribution, with improved coprological and serological methods used to detect presence of infection. Diagnostic test correlates intensity of infection and associated production losses such as carcass weight and milk yield (Mungube et al., 2006; Charlier et al., 2014). Sellers and buyers of cattle meat (beef) in Gombe are ignorant of the danger in consuming infected livers, due to lack of public education.

The animals are reared under the free range extensive management system. The animals range freely grazing grasses in the fields. Their feeding on grasses is supplemented with fodder particularly during the dry season when there is scarcity of grasses. The animals usually graze on grasses and leaves near water holes, rivers, lakes and temporary flooded areas within the grazing area or range. The animals may acquire infections from such areas that are infested with metacercariae. Information on whether or not the animals are treated or dewormed against fascioliasis is unavailable. Thus, untreated or un-dewormed animals will continue to shed fasciola eggs in their faeces and could serve as a source of infection to healthy animals. Lymnaea sp. is common in Gombe due to the increase in the number of artificial ponds and dams. The animals overcrowd at water pools particularly during the dry season and this favours the transmission of infection (Kela, 1992; Ralp, 1981). Fasciola hepatica is a physically and economically devastating parasitic nematode whose rise in recent years has been attributed to climate change. Climate change has an impact on the free-living stages of the parasite and its intermediate host Lymnaea truncata (Fox, 2011; Khan et al., 2013).

According to Smyth (1966), fasciola completes its life cycle in two hosts, which are the invertebrate fresh water snails (Lymnea and Planorbis spp.) and the vertebrate definitive host (cattle). Unembryonated fasciola eggs are passed out with the faeces of the definitive host. Under optimum temperature of $25{ }^{\circ} \mathrm{C}-30{ }^{\circ} \mathrm{C}$, moisture and relative humidity of $60 \%$, the eggs embryonate and hatch, releasing ciliated miracidia which swim in fresh water. The miracidia locate and penetrate the snail intermediate host. Within the intermediate host, the miracidia develops into sporocysts and then to redia. The redia give rise to cercaria and then to metacercaria which swim freely and encyst on vegetation at the edge of water. The definitive host (cattle) becomes infected when it feeds on pasture of grasses containing metacercaria. After ingestion, the metacercaria excyst in the duodenum and the larvae emerge through a hole in the cyst wall. The young flukes puncture their way into the body cavity and wander around until they locate the liver capsule which they penetrate. They burrow through the liver tissues and get to the bile ducts. Adults may live for up to eight years in the liver and gall bladder.

Published information on the prevalence of fascioliasis, in cattle in Gombe, is scarce, considering the fact that Gombe is predominantly a cattle rearing area. However, field veterinarians continue to observe the disease at post mortem examination. This study was therefore designed with the view of providing baseline information on the prevalence of fascioliasis in cattle, slaughtered at the Gombe abattoir, Nigeria. The baseline information provided will be useful for planning control measures and programmes against the disease in the area.

\section{MATERIALS AND METHODS \\ Study area}

The research was carried out at the Gombe abattoir, Gombe State, Nigeria.

Gombe (latitude $10^{0} 08^{1} \mathrm{~N}$ and $11^{0} 24^{1} \mathrm{E}$ and longitude $11^{0} 02^{1} \mathrm{~N}$ and $11^{0} 18^{1} \mathrm{E}$ ) experiences two seasons, the rainy season, from April to October and dry season, from November to March. 
Annual rainfall ranges between 1000 $\mathrm{mm}$ to $1200 \mathrm{~mm}$. Average daily temperature is $34{ }^{0} \mathrm{C}$ in April and $27{ }^{\circ} \mathrm{C}$ in August. The relative humidity ranges from $70 \%-80 \%$ in August and decreases to about $15 \%-20 \%$ in December. Swamps and muddy areas are common during the rainy seasons in the State. The natural vegetation is typically that of the Sudan savanna and is composed of shrubs, herbs, grasses and sparsely distributed trees. This provides enough grazing land and pasture for cattle rearing (Gombe master plan, 2003). Cereals such as groundnut, maize, guinea corn, millet and cowpea are predominantly grown in the area and provide enough fodder for the animals.

\section{Sampling procedure and post mortem examination of the liver for fascioliasis}

Three hundred and twenty (320) cattle were examined, which comprised of 155 White Fulani, 53 Sokoto Gudali, 92 Red Bororo and 20 Muturu breeds.

Visits were made to the abattoir twice a week for a period of three months (April to June). On each visit, the number of cattle slaughtered, the breed, sex and age were noted. The animals slaughtered in the abattoir were bought from the Tashan Dukku and Pantami cattle markets in Gombe. The animals were brought from other parts of the State and from neighbouring States like Borno, Yobe, Adamawa, Bauchi, Taraba and Kano States.

\section{Breed determination White Fulani}

The White Fulani breed has a commonly white coat colour on a black skin with black ears, eyes, muzzles, hooves, horn and tail tips. The breed is characterized by medium to long, high lyre shaped horns. That is, the horns are slender, medium to long size, measuring 81-107 $\mathrm{cm}$ and are lyre shaped, curved outwards and upwards, with an outward turn at the tip. It either has welldeveloped thoracic humps or humps intermediate with the cervico-thoracic humps. The head is long, wide across the fore head and with a straight or concave appearance. The neck is strong, providing an upward carriage for the head. The average adult wither height is $130 \mathrm{~cm}$. The udder is welldeveloped, of a good shape and strong attachment. The teats are well positioned and are of medium to reasonably large size (Tawah and Rege, 1996; Gates, 2007). The general shallowness of the body and lack of width, gives the breed a leggy appearance.

\section{Red Bororo}

The Red Bororo has red coat colour, with long and lyre shaped horns measuring 80 to $105 \mathrm{~cm}$. This breed is adapted to long distance trekking in the pastoral management system. The Red Bororo is more tolerant to heat and trypanosomiasis than the Sokoto Gudali and more resistant to dermatophilosis and intestinal helminthes than the Muturu thus, has low mortality rate (Tawah and Rege, 1996; Gates, 2007). It is the most numerous and wide spread breed in Nigeria, representing about $37.2 \%$ of the national cattle population. It has excellent potentials for milk and beef and its conformation and body size makes it suitable for draught. It's average lactation period is about 220 days. The average birth weight ranges from 18.2 to $24.2 \mathrm{~kg}$. The mature weight of bulls and cows in the improved system of management is 350 to 665 and 250 to $380 \mathrm{~kg}$ respectively. The slaughter and carcass weights are 325 and 166 $\mathrm{kg}$.

\section{Sokoto Gudali}

The Sokoto Gudali has multiple coat colours and the most common one is the black and white coating with light underside, with very short horns. The Sokoto Gudali has deeper body than the White Fulani breed. The head is long and wide between the eyes and across the forehead, with a straight or slightly convex facial profile. The ears are long, large and convex, sometimes pendulous. The hump is thoracic in position. The average ranges from 130 to $138 \mathrm{~cm}$ for males and 116 to 132 $\mathrm{cm}$ for females. This breed is owned and managed by Fulani and Hausa pastoralists and 
transhumant herders (Gates, 2007) who feed them on communally owned grazing lands and browse especially in the dry season. This breed is known for its hardiness to the arid northerly environments and its beef quality and milk. The mature weight ranges from 495 to $660 \mathrm{~kg}$ for males and 240 to $355 \mathrm{~kg}$ for females.

\section{Muturu breed}

The Muturu breed has black and white patches of coat colour, with large udder for milk production (Getty et al., 1975; Gate, 2007). It is the smallest cattle breed known. The height for withers is $95 \mathrm{~cm}$ for males and $88 \mathrm{~cm}$ for females. The weight is $147.2 \mathrm{~kg}$ for males and $110.0 \mathrm{~kg}$ for females. The management level where these cattle are kept is low. The breed maintains good body by grazing and browsing throughout the year. The breed is trypanotolerant and also tolerates ticks and tick-borne diseases. It has significant cultural values and is used for socio-cultural purposes, sacred and dedicated to shrines. It is sometimes used for work and is seldom milked.

\section{Sex determination}

The sex was determined by observing the genitals or sex organs. Male cattle (bulls) have a penis, while female cattle (cows) have a vagina.

\section{Age determination}

The age was determined using dentition according to (Getty et al., 1975). Cattle less than one year old (young) had temporary incisors that erupted at birth but could also have deciduous molars or premolars and never both.

For cattle between one to three years of age, which were considered as young adults, those between 13 - 14 months had their full set of deciduous incisors but were temporary short, broad and bright. Those between 15 18 months of age had their deciduous incisors evident. The incisors were larger and narrower when compared with those of $13-14$ months of age. The eruptions of the first central permanent incisors were indicative of cattle between 18 - 24 months of age. Cattle aged between 25 - 36 months had their middle incisors well erupted and developed permanently. The eruption of the second and third intermediate incisors indicated that the animal was 36 months old. Cattle above three years of age, which were considered as adults, had their incisors erupted and a few of them had their teeth worn down.

The number of cattle slaughtered at the abattoir, the breed, sex and age, were confirmed by veterinary officers on duty at the abattoir.

\section{Post mortem examination of the liver for fascioliasis}

Livers of the slaughtered cattle were inspected and observed thoroughly, with the aid of hand lens. The adult flukes were seen by way of the paths made by them, which were identified white strips of lines in the hepatic parenchyma. These paths, together with the bile ducts were pressed and incised length-wise, for the collection of adult liver flukes. Colour, presence of worms and or white strips of lines in the liver were used to detect infection (Amadi and Egbuline, 2007). The infected livers usually had several fibrous tissues, hard and light brown in colour, and had offensive odour.

\section{Data analysis}

The term prevalence was obtained as described by Margolis et al. (1982) and express as a percentage.

The Chi square test was used to determine any possible association between infection with age, sex and breed of cattle (SPSS, 1999).

Breed specific prevalence

Ho: There is no difference in the prevalence of fascioliasis in the different breeds of cattle examined.

Ha: There is difference in the prevalence of fascioliasis in the different breeds of cattle examined.

$$
\begin{aligned}
& \alpha=0.05 \text { (p-value) } \\
& \text { df }=3
\end{aligned}
$$


Decision: Reject Ho if $\mathrm{X}_{\text {cal }}^{2} \geq \mathrm{X}^{2}$ tab Accept Ho if $\mathrm{X}^{2}{ }_{\text {cal }} \leq \mathrm{X}^{2}{ }_{\text {tab }}$

Calculation

$\mathrm{X}_{\text {cal }}^{2}=20.70000$

$\mathrm{X}_{\text {tab }}^{2}=7.81473$

Conclusion

Reject Ho since $X_{\text {cal }}^{2} \geq X^{2}$ tab

There is difference in the prevalence of fascioliasis in the different breeds of cattle examined $(\mathrm{p}<0.05)$.

1. Sex specific prevalence

Ho: There is no difference in the prevalence of fascioliasis in males and females.

Ha: There is difference in the prevalence of fascioliasis in males and females.

$$
\begin{aligned}
& \alpha=0.05 \text { (p-value) } \\
& \mathrm{df}=1
\end{aligned}
$$

Decision: Reject Ho if $\mathrm{X}_{\text {cal }}^{2} \geq \mathrm{X}^{2}$ tab

Accept Ho if $\mathrm{X}^{2}$ cal $\leq \mathrm{X}^{2}$ tab

Calculation

$\mathrm{X}_{\text {cal }}^{2}=3.98000$

$\mathrm{X}_{\mathrm{tab}}^{2}=3.84146$

\section{Conclusion}

Reject Ho since $\mathrm{X}_{\text {cal }}^{2} \geq \mathrm{X}^{2}$ tab. There is difference in the prevalence of fascioliasis in males and females $(\mathrm{p}<0.05)$.

\section{Age specific prevalence}

Ho: There is no difference in the prevalence of fascioliasis in young, young adults and adult cattle.

Ha: There is difference in the prevalence of fascioliasis in young, young adult and adult cattle.

$\alpha=0.05$ (p-value)

$\mathrm{df}=2$

Decision: Reject Ho if $\mathrm{X}_{\text {cal }}^{2} \geq \mathrm{X}^{2}{ }_{\text {tab }}$

Accept Ho if $\mathrm{X}_{\text {cal }}^{2} \leq \mathrm{X}^{2}$ tab

Calculation

$\mathrm{X}_{\text {cal }}^{2}=19.30000$

$\mathrm{X}_{\text {tab }}^{2}=5.99147$

Conclusion

Reject Ho since $X_{\text {cal }}^{2} \geq X^{2}$ tab

There is difference in the prevalence of fascioliasis in young, young adult and adult cattle $(\mathrm{p}<0.05)$.

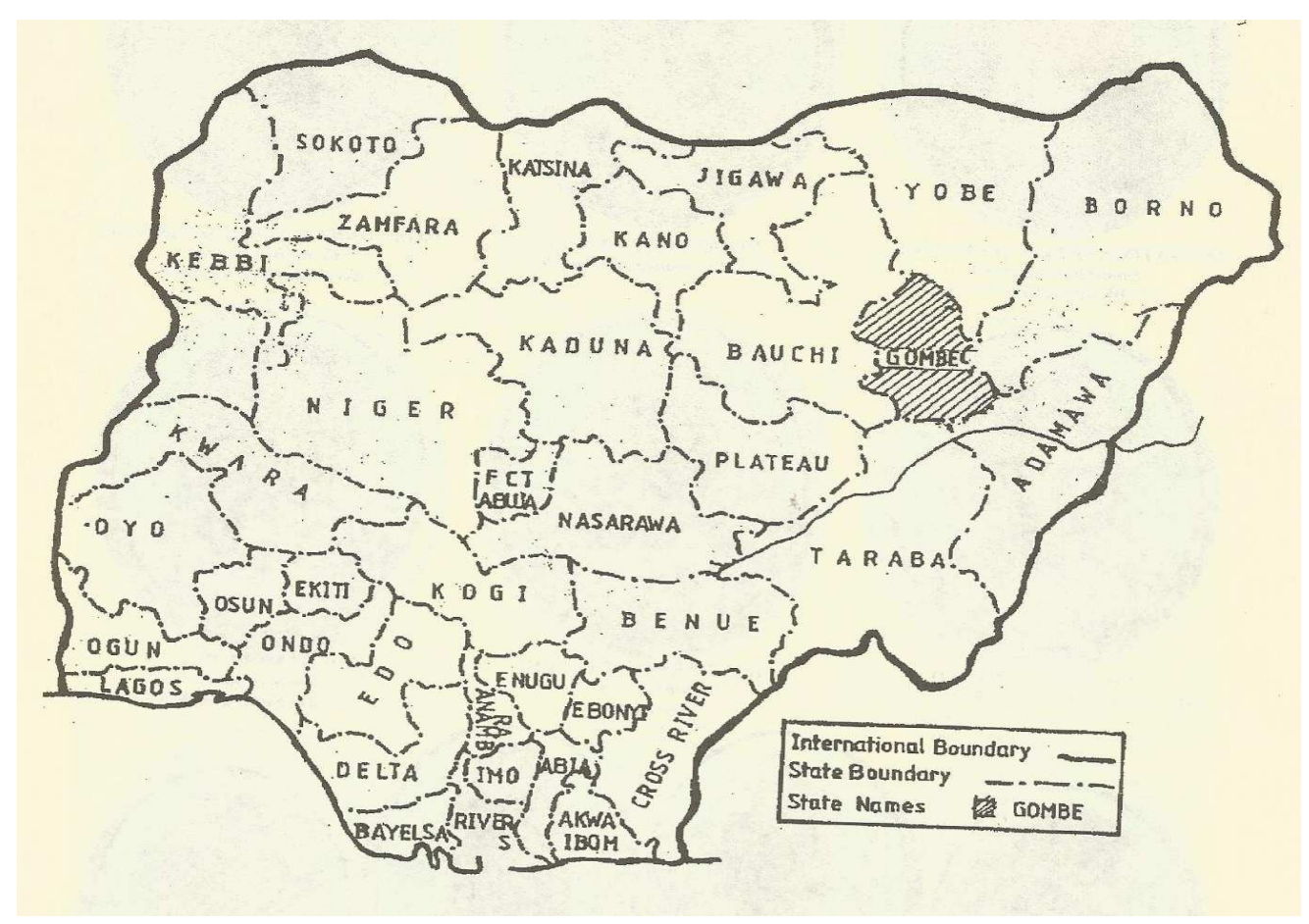

Figure 1: Map of Nigeria showing Gombe. 


\section{RESULTS}

Out of the 320 cattle examined 83 $(25.9 \%)$ were infected with fascioliasis. This comprised of $56(36.1 \%)$ White Fulani, 20 $(21.7 \%)$ Red Bororo, 7 (13.2\%) Sokoto Gudali and $0(0.0 \%)$ Muturu breeds (Table 1). The White Fulani breed was more infected by fascioliasis, followed by the Red Bororo, the Sokoto Gudali and the Muturu breeds. The difference in the prevalence of fascioliasis in the different breeds of cattle examined was significant $(\mathrm{p}<0.05)$.

Male cattle had higher infection with fascioliasis $66(29.1 \%)$ than females 17 (18.3\%).
Males were more infected than females. The sex specific prevalence indicated significant difference $(\mathrm{p}<0.05)$.

The age specific rates of infection were $52(37.4 \%)$ in adults, $27(20.1 \%)$ in young adults and $4(8.5 \%)$ in young (Table 1). Adults were more infected, followed by young adults and young.

There was significant difference in the prevalence of fascioliasis in young, young adult and adult cattle $(\mathrm{p}<0.05)$.

Table 1: Prevalence of fascioliasis in cattle slaughtered at Gombe township abattoir, Gombe State, Nigeria $(\mathrm{N}=320)$.

\begin{tabular}{|c|c|c|c|c|}
\hline \multirow[b]{2}{*}{ Breed of cattle } & \multicolumn{2}{|c|}{ Prevalence by Sex } & \multicolumn{2}{|c|}{ Prevalence by Age } \\
\hline & $\begin{array}{l}\text { Number } \\
\text { examined }\end{array}$ & $\begin{array}{l}\text { Number } \\
\text { Infected (\%) }\end{array}$ & $\begin{array}{l}\text { Number } \\
\text { examined }\end{array}$ & $\begin{array}{l}\text { Number } \\
\text { Infected }(\%)\end{array}$ \\
\hline \multirow[t]{4}{*}{ White Fulani } & 155 & $56(36.1)$ & 155 & $56(36.1)$ \\
\hline & స102 & 万43 (42.2) & $<1 \mathrm{yr} \quad 30$ & $<1 \mathrm{yr} \quad 4(13.3)$ \\
\hline & $q 53$ & q $13(24.5)$ & $1-3 y r s 31$ & $1-3 y r s 9(29.0)$ \\
\hline & & & $>3 y r s 94$ & $>3 y r s \quad 43(45.7)$ \\
\hline \multirow[t]{4}{*}{ Red Bororo } & 92 & $20(21.7)$ & 92 & $20(21.7)$ \\
\hline & $0^{7} 70$ & ${ }^{\lambda} 16(22.9)$ & $<1 \mathrm{yr} 10$ & $<1 \mathrm{yr} \quad 0(00.0)$ \\
\hline & q22 & ㅇ 4 (18.2) & $1-3$ yrs 69 & $1-3 y r s ~ 17(24.6)$ \\
\hline & & & $>3$ yrs 13 & $>3 \mathrm{yrs} \quad 3(23.1)$ \\
\hline \multirow[t]{4}{*}{ Sokoto Gudali } & 53 & $7(13.2)$ & 53 & $7(13.2)$ \\
\hline & $\pi 41$ & ô $7(17.1)$ & $<1 \mathrm{yr}$ & $0(00.0)$ \\
\hline & q12 & q0 (00.0) & $1-3$ yrs 18 & $1-3 y r s \quad 1(5.6)$ \\
\hline & & & $>3$ yrs 30 & $6(20.0)$ \\
\hline \multirow[t]{4}{*}{ Muturu } & 20 & $0(00.0)$ & 20 & $0(00.0)$ \\
\hline & ठ̂14 & ఫ0 (00.0) & $<1 \mathrm{yr} \quad 2$ & $0(00.0)$ \\
\hline & q 6 & $+0(00.0)$ & $1-3$ yrs 16 & $1-3 y r s \quad 0(00.0)$ \\
\hline & & & $>3 y r s \quad 2$ & $>3 y r s \quad 0(00.0)$ \\
\hline \multirow[t]{4}{*}{ Total } & 320 & $83(25.9)$ & 320 & $83(25.9)$ \\
\hline & 3227 & $66(29.1)$ & $<1 \mathrm{yr} \quad 47$ & $<1 \mathrm{yr} \quad 4(8.5)$ \\
\hline & 우 93 & 우 $17(18.3)$ & $1-3 y r s 134$ & $1-3 y r s 27(20.1)$ \\
\hline & & & $>3$ yrs 139 & $>3 y r s \quad 52(37.4)$ \\
\hline
\end{tabular}




\section{DISCUSSION}

The study revealed an overall prevalence of $25.9 \%$, higher than $18.0 \%$ reported by Abolarinwa and Aroyehun (2005) in Minna abattoir, but lower than $32.3 \%$ reported by Ejima and Akor (2013) in Minna metropolis, $40.0 \%$ by Amadi and Egbuline (2007) in Umuahia Central Abattoir, 46.54\% by Hassan and Anwo (2010) in Isheri Olofin, $54.0 \%$ by Idris et al. (2004) in Gwagwalada abattoir, and $60.74 \%$ by Wulha and Banke (2001) in Makurdi metropolis. The differences in the overall prevalences in these studies may be due to differences in the periods of study, vegetation, weather and other climatic factors prevailing in the areas of study. Gombe is found within the sudan savanna, while Minna and Gwagwalada are in the northern guinea savanna, Makurdi is in the southern guinea savanna and Umuahia is in the tropical rainforest. Rainfall and relative humidity are higher in the other areas than in Gombe. Temperatures are higher in Gombe compared to the other areas. Thus, areas with high infection rates may have conducive environmental factors such as high relative humidity, high rainfall, low temperature, availability of water and moisture, which are the basic requirements for the parasite to complete its life cycle and which also greatly influence transmission efficacy (Fox, 2011). These factors also favour the thriving and abundance of the snail intermediate hosts (Smyth, 1969; Urquhart et al., 1996). Phiri (2005) reported that higher prevalence of fascioliasis in cattle occurs in the raining season than in the dry season. This is obvious since the rainy season generally presents a more favourable climate for the completion of the life cycle of the parasite than the dry season, when the cercariae and the snail intermediate hosts have low survival rates. The present study was carried out in the rainy season (April to June) and is perhaps the reason why a prevalence of $25.9 \%$ was observed. The prevalence may have been lower if the study was carried out in the dry season.
High prevalence of infection may also be due to poor sanitary conditions of herds, host susceptibility to infection as a result of poor feed quality, ill-treated tributaries, carefree attitude of both herdsmen and health supervisors and lack of proper control programmes, as well as poor veterinary services in the study area against the disease (Wulha and Banke, 2001). This high prevalence may have serious economic impacts on both cattle and humans. Such economic losses could consist of costs of anthelminthic, drenches, labour, liver condemnation at meat inspection and losses in production due to mortality, reduction in meat, milk and wool production and reduction in growth rate, fertility and draught power. The disease could be public health significance, causing human fascioliasis (Saleha, 1991).

The high prevalence rate of infection observed in the white Fulani breed, and the Muturu breed which was found to have no infection, implies that, some breeds are more susceptible to infection than others. This may be attributed to the numbers of these breeds slaughtered at the abattoir. This could also be connected with the differences in the host intrinsic factors (genetic, physiology and immunity) and extrinsic factors (environmental and management practices).

The higher prevalence in males (bulls) than in females (cows) suggests that male animals are more susceptible to fasciola infections than females, which may be due to their physiognomic differences. This may also be attributed to the practice of slaughtering more male than female animals in the abattoir, since the female animals are retained for breeding and milk production (Phiri, 2005).

This observation, however, disagrees with the reports of Wulha and Banke (2001), Idriset al. (2004), Abolarinwa and Aroyehun (2005), Phiri (2005) and Ejima and Akor (2013), who reported higher prevalences in female than male animals.

The higher prevalence in adults than in young adults and young may be attributed to the lesser exposure of the young animals to 
the parasite and the type of feed taken by the young animals. Young animals normally feed on milk and chaff, around the base of the Fulani huts, while the adults graze on grasses, leaves and other vegetation, mainly in controlled pastures especially along river banks. They are also driven from place to place in search of green pastures and water during the dry season. There is often a high concentration of the snail intermediate hosts in permanent water bodies, which may contaminate the water and the nearby vegetation with encysted metacercariae. Most of the cattle slaughtered at the abattoir are adults, while the young ones are being retained for fattening to adult size before slaughtering. Idris et al. (2004) and Abolarinwa and Aroyehun (2005), however reported higher prevalences in young adults than adults.

Differences in sex, age and breed specific prevalences were statistically significant, thus sex, age and breed could be risk factors.

The study concludes that fascioliasis is a common disease to cattle in Gombe, and thus recommends that proper meat inspection at the abattoir should be adopted, to avoid the selling of infected livers, and the public should be educated on the need to avoid the consumption of infected livers.

Veterinary officers should insist on meat sellers who refuse to discard infected livers after condemnation to do so and a penalty or fine meted out to those who outrightly refuse to comply.

Meat sellers and buyers as well as meat inspectors, should be educated on how to recognize infected livers either by colour or presence of worms or white strips of lines produced by the movement of the worms. This will be better for meat inspectors as a form of continue in service training.

Poverty and ignorance of the disease should be eradicated. The youths should be gainfully employed and the women empowered through skill acquisition to be self-reliant. This will reduce the poverty level in the area. Health talks could the organized at the abattoir to educate the public on the risk of consuming infected livers. Reduction of worm burden through chemotherapy and eradication should be encouraged (Mulcahy et al., 2001; Flynn et al., 2010; Fairweather, 2011). However, it should be noted that Fasciola hepatica can modulate the immune response to some co-infections and that only very few flukicidal drugs are available to treat bovine fascioliasis, many of which have low efficacy against juvenile stages of the parasite. There is also evidence for the development of drug resistance (Charlier et al., 2014). Cattle handlers should treat all the cattle immediately any sign of infection is noticed.

Reduction of snail intermediate host population through the use of molluscicides should also be encouraged. Rearers should not graze cattle around streams particularly during the dry season where there may be high concentration of metecercariae.

Further studies should be carried out on the environment for snails and parasite, the public health importance of the disease, risk factors of the disease and to determine the prevalence of the disease in the dry season, as well as the histopathological effects (Gajewska, 2005) of the parasite on the liver.

\section{ACKNOWLEDGEMENTS}

We are grateful to Dr. B.Y. Kaltungo, Mr. Samuel Madaki and Mr. Gabriel E. of the Veterinary Clinic Zone A, Gombe for technical assistance and guidance during sampling.

\section{REFERENCES}

Abolarinwa SO, Aroyehun A. 2005. Gastrointestinal and liver helminth parasites of cattle in Minna, Niger State. Book of abstracts $3^{\text {rd }}$ Annual conference of the Zoological Society of Nigeriap.16.

Amadi ANC, Egbuline A. 2008. Prevalence of fascioliasis in cattle slaughtered in Umu'ahia central abattoir, Abia State, Nigeria. Book of Abstracts $5^{\text {th }}$ Annual Conference of the Zoological Society of Nigeria p.38. 
Castelino JB, Preston TM. 1979. The influence of breed and age of cattle, on the prevalence of bovine fascioliasis in Kenya. British Veterinary Journal, 135(2): 198-203.

Charlier J, Vercruysse J, Morgan E, Van Dijk J, Williams DJ. 2014. Recent advances in the diagnosis, impact on production and prediction of Fasciola hepatica in cattle. Parasitology, 141(3): 326-335.

Ejima IAA, Akor SO. 2013. Fascioliasis in cattle slaughtered for human consumption in Minna Metropolis, Niger State, Nigeria. Book of abstracts international conference on science and sustainable development in Nigeria held at University of Ibadan from $13^{\text {th }}$ $17^{\text {th }}$ May 2013.P.4.

Fairweather I. 2011.Reducing the future threat from liver flikes: Realistic prospect or quixotic fantasy. Veterinary Parasitology, 180(1-2): 133-143.

Flynn RJ, Mulcahy G, Elsheikha HM. 2010. Coordinating innate and adaptive immunity in Fasciola hepatica infection.Implications for control. Veterinary Parasitology, 169(3-4): 235-240.

Fox NJ, White PC, McClean CJ, Marion G, Evans A, Hutchings MR. 2011. Predicting impacts of climate change on Fasciola hepatica risk. Animal Health, Scottish Agricultural College, Edinburg, United Kingdom, 6(1): 16126.

Gajewska A, Smaga-Kozlowska K, Wisniewski M. 2005. Pathological changes of liver infections in Fasciola hepatica. Wiadomosciparazytologiczne, 51(2): 115-123.

Gates GM. 2007. Breeds of cattle found in Nigeria. Farm and Forest (Nigeria), 11: 19-43.

Getty R, Sisson S, Grossman JD. 1975. The Anatomy of Domestic Animals. ( $5^{\text {th }}$ edition). W. B. Saunders: Philadelphia.

Hassan AA, Anwo OO. 2010. Trematode egg infection of gall bladder in cattle slaughtered at Isheri Olofin, Ogun State, Nigeria. Book of abstracts $6^{\text {th }}$ annual conference of the Zoological Society of Nigeria, held at Conference Centre, University of Ibadan from $1^{\text {st }}$ $5^{\text {th }}$ March 2010. p.20.

Idris HS, Amota KS, Azare BA, Madara AA. 2004. Prevalence of Fasciola gigantica in cattle slaughtered in Gwagwalada abattoir, Abuja, Nigeria. Abstracts of papers, $2^{\text {nd }}$ national conference of the Zoological Society of Nigeria held at Institute of development research, Ahmadu Bello University, Zaria, Nigeria from $8^{\text {th }}-11^{\text {th }}$ November 2004. p. 23

Kaplan RM. 2010. Fasciola hepatica: a review of the economic impact in cattle and consideration for control. Veterinary Therapeutics: Research in Applied Veterinary Medicine, 2(11): 40-50.

Khan MK, Sajid MS, Riaz H, Ahmad NE, He L, Shahzad M, Hussaini A, Khan MN, Iqbal Z, Zhao J. 2013. The global burden of fascioliasis in domestic animals with an outlook on the contribution of new approaches for diagnosis and control. Parasitology Research, 112(7): 2421-2430.

Margolis L, Esch GW, Holmes JC, Kuris AM, Schad GA. 1982. The use of ecological terms in parasitology (Report of an Ad Hoc Committee of the American Soceity of Parasitology). Journal of Parasitology, 68(1): 131-133.

Mulcahy G, Dalton JP. 2001. Cathepsin L. proteinases as vaccines against infection with Fasciola hepatica (liver fluke) in ruminants. Research in Veterinary Science, 70(1):83-86.

Mungube EO, Bauni SM, Tenhagen BA, Wamae LW, Nginyi JM, Mugambi JM. 2006. The prevalence and economic significance of Fasciola gigantica and Stilesia hepatica in slaughtered animals in the Semi-arid Coastal Kenya. Tropical Animal Health and Production, 38(6): 475-483. 
Phiri M. 2005 Prevalence of fascioliasis in Zambia cattle observed at selected abattoirs with emphasis on age, sex and origin. J. Vet. Med., 52: 414-416.

Tawah CL, Rege JEO. 1996. White Fulani cattle of West and Central Africa. Animal Genetic Resources Information Bulletin, 17: 137-158.

Urquhart GM, Armour J, Duncan JL, Dunn AM, Jennings FW. 1996. Veterinary Parasitology (Second Edition). Blackwell Science Ltd.: Oxford, London.
Wulha J, Banke ROK. 2001. A survey of digenetic infection among cattle and goats in Makurdi Metropolis: Book of abstracts $3^{\text {rd }}$ annual conference of the Zoological Society of Nigeria. p. 14.

Young MD, Hall RS, Jex AR, Cantacessi C, Gasser RB. 2010. Elucidating the transcriptome of Fasciola hepatica - a key to fundamental and biotechnological discoveries for a neglected parasite. Biotechnology Advances, 28(2): 222-231. 